\title{
THE IMPACT OF THE EPIDEMICS OF 1727-1730 IN SOUTH WEST WORCESTERSHIRE
}

\author{
by
}

\section{J. A. JOHNSTON}

Charles Creighton was in advance of his time when he wrote in 1894 'the actual history of old fevers, their epidemic prevalence, their incidence upon rich and poor, upon children or adults, their fatality, their contagiousness, their connexion with the seasons and other vicissitudes of the people-all this is something more than curious.' 1 It was another sixty years before there was general academic appreciation amongst demographers and historians of his emphasis on the importance of disease in any explanation of population trends. Only in the last fifteen years have there been sustained attempts to answer some of the questions posed by his work. The check on population growth represented by disease is now recognized as a central issue in the discussion of many old and new historical problems, particularly those associated with the immediately pre-industrial phases of British history. In the study of eighteenthcentury English demography the heavy mortality of the years $1727-1730$ has assumed great significance. It appears to have been the last catastrophic epidemic of preindustrial England. The population increase of the late eighteenth and early nineteenth centuries which was to provide the foundation of industrial and imperial power has been linked to the high death rate of these years. The deaths between 1727 and 1730, it is argued, led to early and fruitful marriages amongst the survivors. The offspring of these marriages grew to nubility in a period of cheap food and favourable economic opportunity and in their turn married during the period 1755 to 1764 , earlier than had been customary. The children of these marriages were also lucky in that they reached the age of marriage in a period of prosperity and opportunity and they too could contract early marriages. This theory, based on a treble wave of 'bulge' generations, explains how the eighteenth-century population became big enough by the end of the century to withstand the economic and national hardships of the Napoleonic War period and even increase its rate of expansion. ${ }^{2}$ Yet surprisingly little is known of the mortality that provides the starting point in the progression.

It was a widespread but apparently not a national disaster. There are many and scattered contemporary accounts of the epidemic. Creighton records mortality far above the average during these years in Devonshire, Gloucestershire, Ireland, Norwich and Yorkshire. ${ }^{3}$ The north and east of England seem to have suffered generally and severely.4 The only modern study in which these years have received detailed attention is Dr. Eversley's account of the eighteenth-century demography of twelve parishes

${ }^{1}$ C. Creighton, A History of Epidemics in Britain, ed. D. E. C. Eversley, E. Ashworth Underwood, and L. Ovenall, London, 1965, vol. 2, p. i.

D. E. C. Eversley, 'Population, Economy and Society' and 'Population in Worcestershire 1660 1850', both in Population in History, ed. D. V. Glass and D. E. C. Eversley, 1965, pp. 30-1, 405-6.

C. Creighton, op. cit., vol. 2, pp. 71, 74, 345.

- Autobiography of William Stout of Lancaster 1665-1752, ed. J. D. Marshall, 1967, pp. 201-4; T. S. Ashton, Economic Fluctuations in England 1700-1800, 1959, p. 18; W. G. Hoskins, The Population of an English Village 1086-1801-A Study of Wigston Magna (Leics.) in Provincial England 1964, p. 202; J. W. F. Hill, Georgian Lincoln, 1966, pp. 147, 313. 


\section{Impact of the Epidemics of 1727-1730 in South West Worcestershire}

in north west Worcestershire. ${ }^{5}$ This shows that the west Midlands suffered as well. The deaths in these years have not attracted greater historical attention for a variety of reasons. They were not characterized by the concentration in time that has made the plague of 1665 so famous but were spread out over four or five years in which peaks of mortality seem to have varied from region to region. They were not apparently of any new or readily identifiable disease. Moreover in a country where so much history has been written from the evidence and viewpoint of London and the south east of England the fact that these seem to have escaped the worst manifestations of the mortality has also contributed to historical neglect.

In an attempt to find out something of the characteristics and consequences of the mortality a study has been made of the recorded baptisms, marriages and burials of seventy-one Worcestershire parishes in the south west of the county. These parishes cover an area of about 225 square miles, bounded on the south and west by the

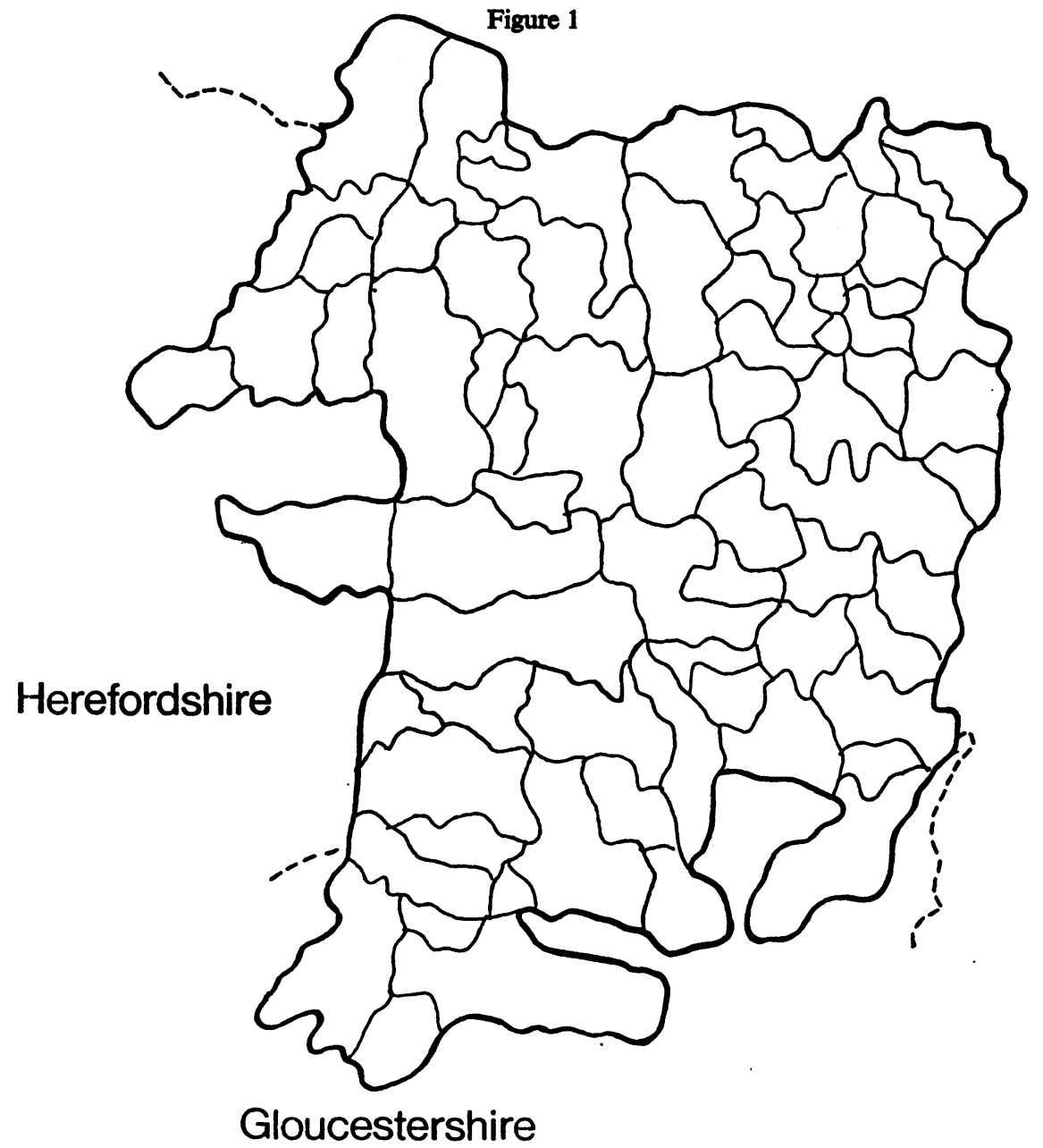

D. E. C. Eversley, 'Population in Worcestershire 1660-1850', op. cit., pp. 408-10. 


\section{J. A. Johnston}

county boundary with Gloucestershire and Herefordshire. It includes all those parishes south of a line from Martley to Himbleton and west of a line from Himbleton to Eckington. ${ }^{6}$ The River Severn runs from north to south through the area which contains eighty of Worcestershire's 209 parishes. The only major town within the area was Worcester with ten parishes. There were also two smaller market towns, Pershore and Upton on Severn. ${ }^{7}$ The three towns between them provided about forty per cent of the area's baptism and burial entries each year. Parish registers and bishops' transcripts provided the basic demographic information. Deficiencies in the records of nine of the parishes within the area made it necessary to omit them from the statistical record. The parishes omitted, with the exception of St. Nicholas of Worcester, were all small, rural and scattered and their omission is not likely to be significant to the discussion which follows. ${ }^{8}$ Although the possible sources of error in an individual

Figure 2

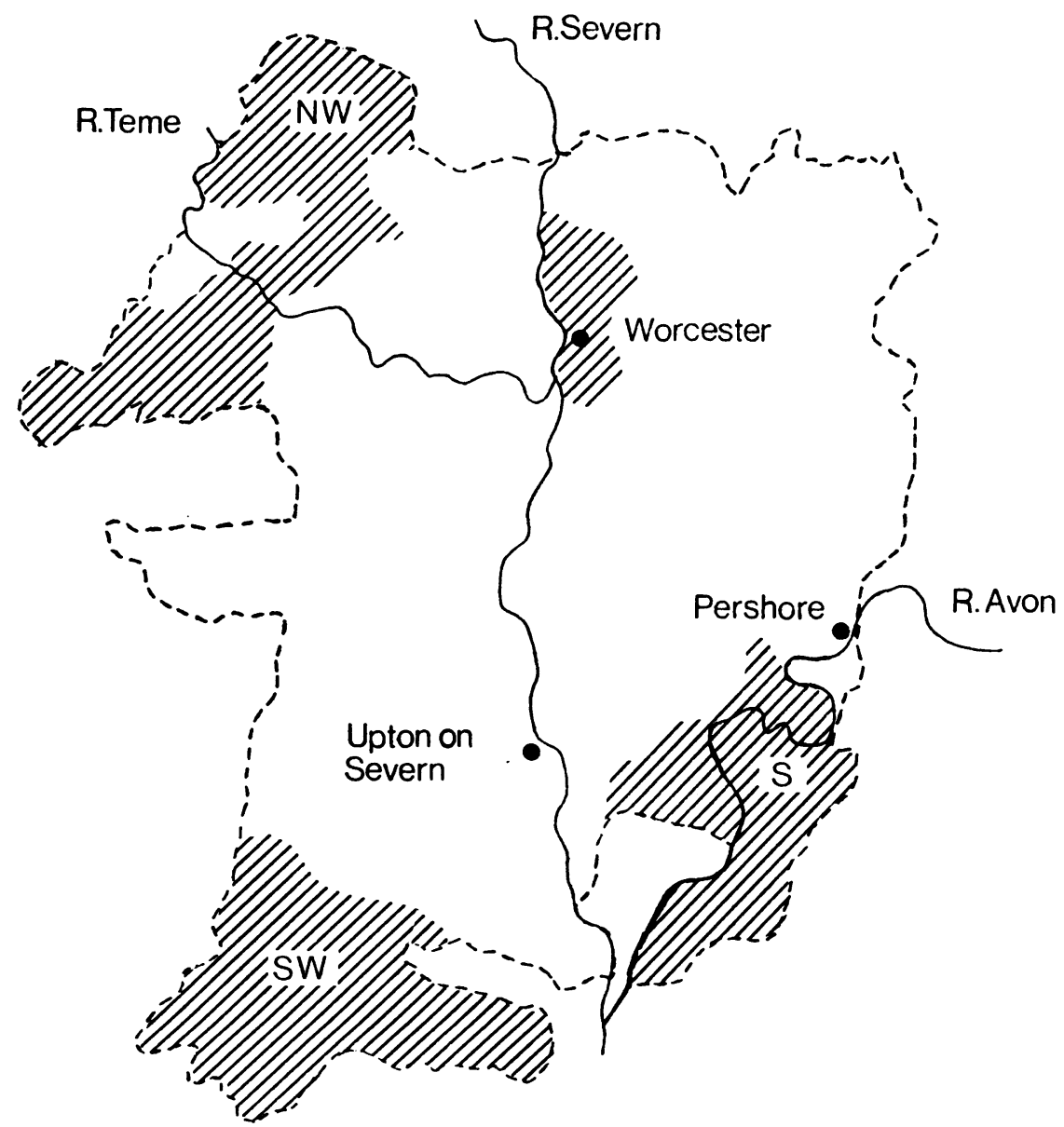

The shaded regions are those dealt with in Figure 3, see p. 285

- See figure 1. ' See figure 2 .

- The parishes omitted are Besford, Bransford, Defford, Martin Hussingtree, Pirton, Pinvin, Queenhill, Ripple and St. Nicholas (Worcester). 


\section{Impact of the Epidemics of 1727-1730 in South West Worcestershire}

parish register are numerous they are not, amongst such a number of parishes for a period of thirty years, likely to be so variable as to invalidate an analysis concerned more with trends than absolute figures.

The annual totals of the marriages, baptisms and burials recorded in the seventy-one parishes between 1711 and 1740 are given in Table 1 . The years from 1711 to 1740 were studied so that the 1727-1730 mortality could be assessed in its chronological context. An assessment of the harvest is included in Table 1 together with an indication of the years in which baptisms outnumbered burials. ${ }^{\circ}$ It can be seen from the table

Table 1

The annual totals of recorded marriages, baptisms and burials in 71 parishes of S.W. Worcestershire between 1711 and 1740 .

\begin{tabular}{|c|c|c|c|c|c|}
\hline Year & Marriages & Baptisms & Burials & $\begin{array}{l}\text { Excess of } \\
\text { Baptisms }\end{array}$ & $\begin{array}{l}\text { Assessment } \\
\text { of harvest }\end{array}$ \\
\hline $\begin{array}{l}1711 \\
1712 \\
1713 \\
1714 \\
1715 \\
1716 \\
1717 \\
1718 \\
1719 \\
1720 \\
1721 \\
1722 \\
1723 \\
1724 \\
1725 \\
1726 \\
1727 \\
1728 \\
1729 \\
1730 \\
1731 \\
1732 \\
1733 \\
1734 \\
1735 \\
1736 \\
1737 \\
1738 \\
1739 \\
1740\end{array}$ & $\begin{array}{l}240 \\
234 \\
306 \\
305 \\
296 \\
358 \\
288 \\
295 \\
274 \\
242 \\
242 \\
267 \\
292 \\
260 \\
334 \\
298 \\
225 \\
259 \\
339 \\
393 \\
338 \\
327 \\
329 \\
311 \\
306 \\
262 \\
241 \\
281 \\
247 \\
230\end{array}$ & $\begin{array}{l}683 \\
631 \\
708 \\
761 \\
809 \\
802 \\
761 \\
846 \\
875 \\
788 \\
804 \\
849 \\
904 \\
795 \\
745 \\
949 \\
829 \\
525 \\
598 \\
626 \\
875 \\
864 \\
889 \\
927 \\
950 \\
893 \\
853 \\
896 \\
948 \\
817\end{array}$ & $\begin{array}{l}941 \\
794 \\
772 \\
767 \\
749 \\
778 \\
678 \\
553 \\
768 \\
778 \\
914 \\
713 \\
774 \\
957 \\
914 \\
819 \\
1,507 \\
1,861 \\
2,130 \\
1,087 \\
833 \\
705 \\
716 \\
764 \\
761 \\
678 \\
777 \\
647 \\
691 \\
669\end{array}$ & $\begin{array}{l}+ \\
+ \\
+ \\
+ \\
+ \\
+ \\
+ \\
+ \\
+ \\
+\end{array}$ & $\begin{array}{l}\text { Deficient } \\
\text { Average } \\
\text { Bad } \\
\text { Good } \\
\text { Average } \\
\text { Average } \\
\text { Average } \\
\text { Good } \\
\text { Average } \\
\text { Average } \\
\text { Good } \\
\text { Good } \\
\text { Good } \\
\text { Average } \\
\text { Deficient } \\
\text { Average } \\
\text { Bad } \\
\text { Bad } \\
\text { Average } \\
\text { Good } \\
\text { Good } \\
\text { Good } \\
\text { Good } \\
\text { Average } \\
\text { Deficient } \\
\text { Average } \\
\text { Average } \\
\text { Average } \\
\text { Deficient } \\
\text { Dearth }\end{array}$ \\
\hline Total & 8,619 & 24,200 & 26,495 & & \\
\hline
\end{tabular}

Table 2

Arithmetic mean of marriages, baptisms and burials for three periods between 1711 and 1740

\begin{tabular}{|c|c|c|c|}
\hline Period & Marriages & Baptisms & Burials \\
\hline $1711-26$ & 283 & 795 & 792 \\
$1727-30$ & 304 & 645 & 1,647 \\
$1731-40$ & 287 & 891 & 724 \\
\hline
\end{tabular}

- W. G. Hoskins, 'Harvest fluctuations and English economic history 1620-1759', Agricultural History Review, 1968, 16, pt. I, 16-18. 


\section{J. A. Johnston}

that the worst year for deaths, 1729 , was followed by a year which saw the greatest number of marriages and that five years after this, in 1735, occurred the highest number of baptisms for any year in the period. In more general terms the demographic changes of the period are summarized in Table 2.

In the fifteen years before the epidemic period of 1727-30 the margin of baptisms over burials was a small one. Then in the years of epidemic the number of burials more than doubled. At the same time marriages increased and the number of baptisms was decisively reduced. In the decade after the epidemic the number of marriages a year declined to a level near that of the pre-epidemic period, though this figure in a reduced population presumably represents a higher overall marriage rate. The burial figures remain lower than ever before but the most significant aspect of the figures for the decade 1731-40 is the large surplus of baptisms over burials. The conventional explanation of the relationship of the marriage, baptism and burial figures after 1727 would be on the following lines. The high death rate of the years $1727-30$ would have created a favourable economic environment in all levels of society which would have led to marriage at an age earlier than the one normal before the epidemics. Elder sons succeeded to lands and businesses earlier than they would have expected, younger sons suddenly became heirs. Daughters found themselves endowed with the economic attraction of newly inherited possessions. In those classes of society unlikely to receive significant increments of wealth at the death of their elders the mortality had created a situation in which promotion and secure positions were more easily obtainable than before. In theory marriage became possible to many who would presumably have waited several years before accepting the responsibilities of marital status if the epidemics had not occurred. The marriage figures from 1730 to 1735 support this reasoning. These newly-weds, because of their age, the cheap food of the $1730 \mathrm{~s}^{10}$ and the economic environment that followed the epidemics, were able to produce larger and healthier families than had been common earlier in the eighteenth century. Again the baptism figures support this generalization but many problems arise from a more detailed consideration of the epidemics and their consequences.

The first of these problems concerns the nature of the epidemic itself. There seems little doubt that the major killing agent was a fever or fevers. Creighton's evidence on this issue is convincing, if rather confused. Contemporary description of an illness was frequently descriptive rather than clinical. Types of fever were usually described as nervous, hysteric, comatose, inflammatory, relapsing or variolus. Such terminology must often have overlapped in that these terms would have been used to describe the dominant symptom of the same fever at different stages in its progression. ${ }^{11}$ Moreover high temperature was a common symptom of many diseases and the word 'fever' a convenient term to which death from a wide range of illness could be attributed, especially by those unskilled in medicine. In the parish registers of Severn Stoke (S.W. Worcs.) reasons were given for the deaths of thirty-one of the burial entries between 1711 and 1719.12 Nine died of smallpox, one 'suddenly' and one of age. One was stillborn, others died of dropsy, impostume (2), stone, and fifteen of

${ }^{10}$ Lord Beveridge, Prices and Wages in England, 1965, vol. 1, pp. 716, 721 ; T. S. Ashton, op. cit., p. 181 .

${ }_{11}$ C. Creighton, op. cit., vol. 2, pp. 66-73.

12 Worcestershire Record Office (hereinafter W.R.O.) x985.06, B.A.3517. 


\section{Impact of the Epidemics of 1727-1730 in South West Worcestershire}

fever. Such detail is exceptional, most registers simply record the fact of burial, and even in the Severn Stoke registers reasons are not given for all deaths. The difficulties of historical diagnosis are made worse by the possibility that the high death rate between 1727 and 1730 was the work of a fever which is now extinct and beyond the knowledge of medical science. There is some evidence for either new strains of fever or of changes in the virulence of fevers causing new symptoms and fatal illnesses in 1661 and 1716-18. ${ }^{13}$ The disastrous fever epidemics of 1727-30 could have sprung from the latter. In modern terminology the killing fevers are cholera, diphtheria, dysentery, measles, scarlet fever, smallpox, typhoid and typhus. From contemporary description and experience it seems likely that one or both of the last two named, or a disease similar to them, were responsible for many of the deaths in the 1727-30 epidemics. Typhus is acutely infectious and is characterized by rapid spreading and widespread epidemics. ${ }^{14}$ It is particularly destructive of age groups over fifty years, and this does seem to have been a feature of the years $1727-30 .{ }^{15}$ It is moreover frequently associated with national catastrophes like war or famine, and the years 1727 and 1728 were the only two consecutive years between 1711 and 1740 in which there were bad harvests. However the eruptions on the skin which are the most obvious symptoms are not often mentioned in contemporary accounts. ${ }^{16}$ The most commonly reported symptoms of a nervous, remittent fever are more likely to record the prevalence of typhoid, a disease often borne by water, from which Worcester suffered severely until 1895 .

Mortality in 1727 and 1728 was heaviest in the summer and autumn and these two epidemics in their scope, sudden onset and severity have many of the characteristics of typhoid. A fever was certainly the main cause of death at this time. In the parish of Middle and North Littleton, near Evesham in south east Worcestershire, it was recorded in the parish register for 1727 that the fever proved 'very mortal'. ${ }^{17}$ In the parish of Trentham in the adjacent county of Staffordshire fever killed 70 of the 151 people who were buried between 1727 and $1729 .{ }^{18}$ The incidence and peaks of mortality in both these parishes were similar to those in the majority of parishes of south west Worcestershire. It seems reasonable to assume that the same fever was the cause. The summer epidemics of 1727 and 1728 were described by a Yorkshire doctor, Hilary, as being caused by a fever which was notable for its lingering nature and intermittent bouts of lassitude, hysteria and hypochondria. ${ }^{19}$ The period of heaviest mortality came in the late winter and early spring of 1729 . The harvests of 1727 and 1728 had been poor ones. In Lancashire at least the spring of 1728 was wet and the summer generally cold except for a transient heat-wave that scorched the growing corn. ${ }^{20}$ The winter of 1728-9 would have been a lean one, it was also a hard one and the consequences on a population already weakened by two years of fever, costly and

18 C. Creighton, op. cit., pp. 8, 63-4.

$14 \mathrm{~F}$. Henschen, The History of Diseases, 1966, p. 64.

15 See below, pp. 286-88.

16 C. Creighton, op. cit., vol. 2, p. 67.

${ }_{17}$ Quoted in the Transcript of the Register of the Parish Church of Bretforton, ed. W. H. Shawcross, Evesham, 1908, vol. 1 .

18 Transcript of the Register for the Parish of Trentham, Staffordshire, ed. F. J. Wrottesley, 1905.

10 C. Creighton, op. cit., vol. 2, pp. 72-73.

${ }^{20}$ Autobiography of William Stout, op. cit., p. 201. 


\section{J. A. Johnston}

relatively scarce provisions, and, in the towns certainly, the cramped conditions of winter living, were severe. Such conditions provided the environment in which typhus could flourish and it seems likely that this disease rather than typhoid was a major cause of the deaths. These conditions were also favourable for the dissemination of other diseases and influenza was certainly a rival to fever in some parts of the country. ${ }^{21}$ Measles, whooping-cough, and smallpox contributed to the national and probably to the Worcestershire mortality. ${ }^{22}$

The chronological impact of the epidemics has already been indicated above. A monthly analysis for twenty-six parishes provided the basis for generalization. These parishes were divided into four groups within the area of study in order to identify variations in the incidence of the epidemics. ${ }^{23}$ One group of six parishes is in the south west corner of the county, one group of five parishes is in the south east of the area studied, seven are in the north west and eight are Worcester parishes. ${ }^{24}$ The monthly total of burials for each group of parishes is plotted in figure 3 .

The beginning of the epidemic was sharp and severe in all four areas. The death rate increased in August 1727 and remained high for two or three months. The lower level to which it then declined was still higher than the average for early 1727 or 1726 . June and July of 1728 were good months but in August there was a return to high burial totals. This epidemic was less protracted in the rural areas but Worcester was to suffer continuously high mortality levels for another year. The third and worst attack began early in 1729, in January in Worcester, in February in the south and south west, and in March in the north west. For three to four months all areas suffered very badly. The disease seems to have reverberated in Worcester itself for when the country districts began to experience a return to normal a high death rate continued in the city. In December more people were buried in Worcester (67) than in any other month of the period. Worcester suffered again from August to October in 1730 but in the other areas, although each had bad months, the worst was over by the summer of 1729 . Outside the broad similarity of three major epidemics within the years 1727 to 1730 there was obviously much parochial variation. The most obvious example of this was in March 1729 when the rural parishes of the south west recorded more burials than the far more populous city of Worcester. Yet with every qualification of local variation and acceptance that the epidemics were spread throughout four years the period has a unity in time as one of very considerable mortality, with considerable human grief as well as demographic significance.

There are no clear indications within the area studied of the ways in which the epidemics spread. Parishes throughout the area record the suddenly higher burial figures for August 1727. There is slight evidence outside the county that the fever was well established in Staffordshire and Shropshire a few weeks before Worcester-

21 W. G. Hoskins, The Population of an English Village 1086-1801-A Study of Wigston Magna, in Provincial England, 1964, p. 202; C. Creighton, op. cit., vol. 2, p. 67.

"Isid., vol. 2, pp. 343, 642, 669 .

23 see figure 2.

2 In the south west group of parishes are; Berrow, Chaceley, Eldersfield, Pendock, Redmarley D'Abitot, Staunton: in the south are Bredon, Birlingham, Eckington, Great Comberton and Strensham: in the north west Acton Beaachamp, Alfrick, Broadwas, Lulsey, Martley, Wichenford and Suckely. In Worcester are All Saints, St. Andrew, St. Clement, St. Helen, St. John, St. Martin, St. Michael and St. Peter. 


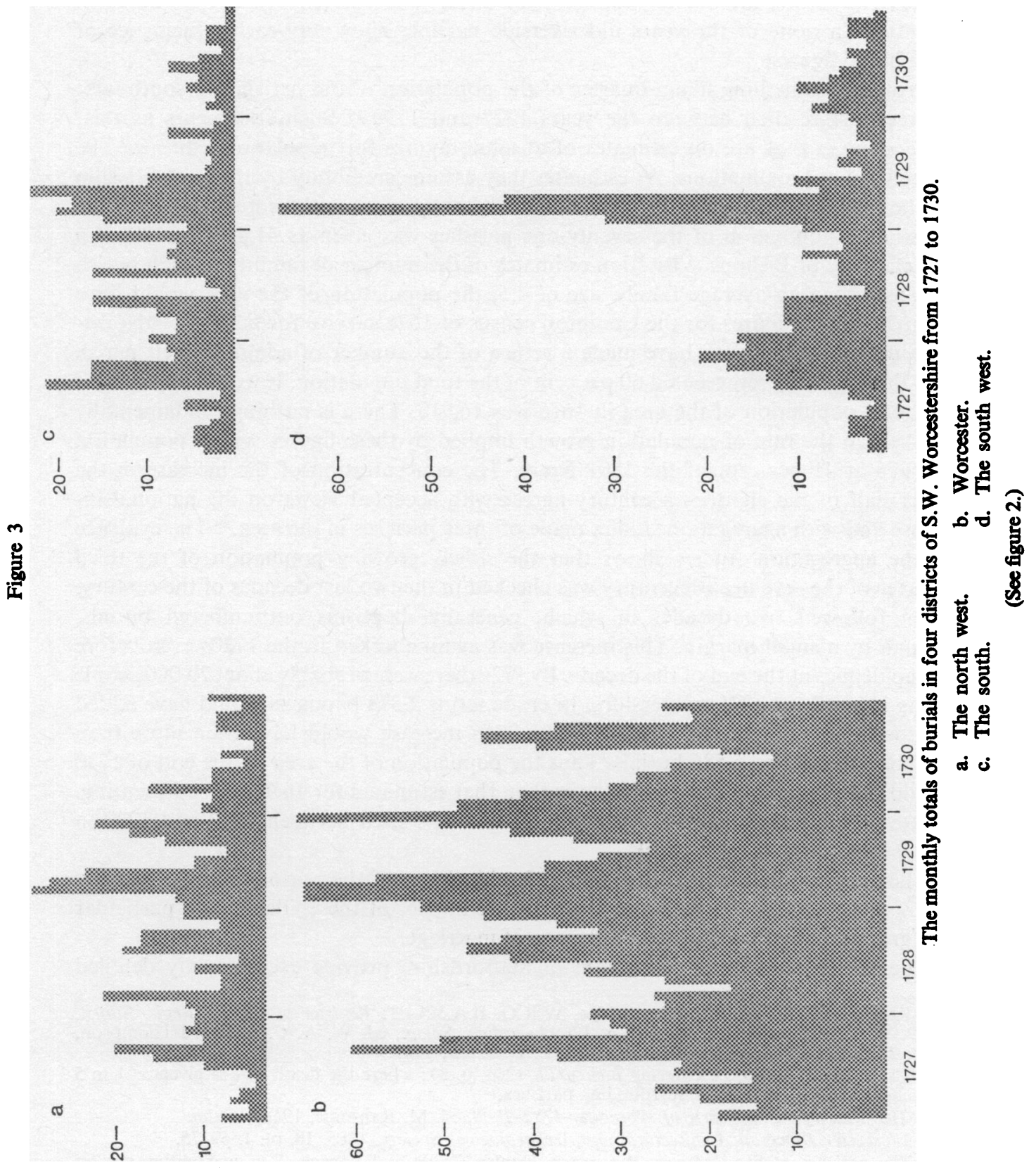




\section{J. A. Johnston}

shire suffered, implying a southerly sweep of the epidemic. ${ }^{25}$ Indeed in many counties outside Worcestershire there were exceptionally high burial figures for 1726 and for many of these counties this year should apparently be included in the epidemic period. The worst months of 1729 were the same in Worcestershire and the adjacent counties. In none of the years did riverside parishes show any earlier incidence of high burial figures.

Probably something like a quarter of the population of the parishes in south west Worcestershire died between the years 1727 and $1730 .{ }^{26}$ Such statements as this, dependent as they are on estimates of absolute figures for population, can never be more than approximations. As estimates they assume credibility by their relationship to the figures produced by the censuses of the early nineteenth century. At the 1801 census the population of the seventy-one parishes was given as 41,497 . In 1782 , on the evidence of Bishops' Visitation estimates of the number of families in each parish and assuming an average family size of 4.5 , the population of the area would have been 29,965. ${ }^{27}$ Figures for the Compton census of 1676 survive for the area. ${ }^{28}$ Normally incumbents seem to have made a return of the number of adults in their parish and this probably represented 60 per cent of the total population. It would appear that the total population of the area in 1676 was 16,918 . There is nothing fundamentally unlikely in the rate of population growth implied by these figures with a population in 1676 at 41 per cent of the 1801 figure. The concentration of the increase in the latter half of the eighteenth century agrees with accepted views on the national increase and with aggregation studies made of three parishes in the area ${ }^{29}$ The evidence of the aggregation studies shows that the slowly growing population of the third quarter of the seventeenth century was checked in the two last decades of the century. Then followed two decades in which, generally, baptisms outnumbered burials, though by a small margin. This increase was again checked in the 1720 s even before the epidemics at the end of the decade. By 1726 there were probably about 20,000 people living in south-west Worcestershire. In crude terms 2,578 baptisms would have added to this figure between 1727 and 1730 but this increase would have been more than counterbalanced by 6,586 burials. Thus the population of the area by the end of 1730 would have been 15,992, a figure lower than that estimated for 1676 and representing, whatever the precise proportion of the people who died between 1727 and 1730, a very severe demographic check.

The recovery of the next decade was rapid. Some of the reasons for the rapidity of this recovery can be seen in a study of the impact of the epidemics on particular age groups and their influence on the age of marriage.

The parish registers of Trentham in Staffordshire provide exceptionally detailed

${ }^{25}$ Register of Oldswinford, Stourbridge, W.R.O. B.A.3214/3; Register of Rowley Regis, Staffs., ed. P. W. L. Adams, 1912; Register of Wrockwardine, Salop., ed. W. A. C. Stratford-Thompson, 1907; Register of Hopton Castle, Salop., ed. E. D. Elton, 1901.

${ }^{36}$ Cf. V. H. T. Skipp, Discovering Bickenhill, 1963, p. 37; where the death rate is given as 1 in 5 in Bickenhill and 1 in 6 in the surrounding parishes.

27 The State of the Bishopric of Worcester 1782-1808, ed. M. Ransome, 1968, passim.

28 Worcester Diocesan Architectural and Archaeological Society, 1885, 18, pt. I, 69-75.

20 The parishes of St. Andrews, Worcester, Hanley Castle and Powick. For aggregation studies see D. E. C. Eversley, 'Exploitation of anglican parish registers by aggregative analysis', in $A n$ Introduction to English Historical Demography, ed. E. A. Wrigley, 1966. 


\section{Impact of the Epidemics of 1727-1730 in South West Worcestershire}

evidence of the epidemics..$^{30}$ They record not only the name of the deceased but also occupation, age and cause of death. This makes it possible to identify the age groups that suffered most from the fevers. The mean age of those who died of fever was 51.3 years. The distribution of the fever deaths by decades is summarized in Table 3. Estimates of age at death are notoriously suspect in the period before civil registration and the ages given in the Trentham register would be very exceptional if they did not include a substantial element of inaccuracy in their estimates of age beyond the first three decades of life. However, even with this qualification the fever at Trentham seems to have been particularly fatal to the elder sections of the population. There is evidence to show that the susceptibility of the aged to the fever was not confined to Trentham. In 1746 Sir Richard Manningham published an essay on the 'Little Fever' which fever he claimed had caused many deaths between 1726 and 1730. In the essay he asserted that the fever was particularly dangerous to 'valetudinarians, delicate persons, and those in the decline of life'. ${ }^{31}$ Modern methods of family reconstitution provide ways in which the opinion of Manningham and the experience of Trentham can be confirmed. ${ }^{32}$ So far only one parish in the area under study, that of Powick, has been studied by means of family reconstitution techniques. The parish registers for Powick before 1663 have been lost but for every decade after this date it is possible to discover the age at death for an increasing number of the inhabitants of the village. A picture of the impact of death by age groups based solely on these precisely ascertained ages of death would be a false one for the early decades of the eighteenth century because it would ignore the considerable number of deaths of parents who were producing children in the last three decades of the seventeenth century but whose own birth dates were probably in the lost volume of the parish register before 1663 . This deficiency can be partially met if it is assumed that parents who were producing children were at least in their twenties. Therefore the parents of young families in the 1690 s would be over fifty years of age if they died during the fevers of 1727-30. For this reason the percentages given in Table 3 for the later age groups in Powick represent an assumed age at death rather than the precise figures which make up the earlier age groups.

Like all attempts at mathematically describing the distribution of death by age group the Table below certainly involves an underestimate of infant mortality but this would be common to both parishes. Such underestimation appears to be a common factor in nearly all English parish registration. The distribution of death by age group in Powick 1727-30 apparently confirms the heavy incidence of mortality amongst the older age groups which is more certainly observed in the more detailed Trentham records. The difference in the distribution of deaths in both parishes between the fever years and those before the epidemics, and for Powick the decade afterwards, is another indication of the heavy destruction of elderly people between 1727 and 1730 . It would be dangerous to assume from the evidence of two parishes that this feature was common to all areas that suffered the epidemics but the possibility is an interesting

${ }^{30}$ Transcript of the Register for the Parish of Trentham, Staffordshire, ed. F. J. Wrottesley, 1905.

31 C. Creighton, op. cit., vol. 2, p. 70.

32 E. A. Wrigley, 'Family Reconstitution' in An Introduction to English Historical Demography, op. cit., $96 \mathrm{ff}$. 


\section{J. A. Johnston}

Table 3

Age at death by decades for the parishes of Trentham (Staffs.) and Powick (Worcs.)

(All figures, except those in the last column, are percentages.)

\begin{tabular}{|c|r|r|r|r|r|r|r|r|r|r|}
\hline & $0-10$ & $11-20$ & $21-30$ & $31-40$ & $41-50$ & $51-60$ & $61-70$ & $71-80$ & $81-90$ & $\begin{array}{c}\text { Total } \\
\text { Deaths }\end{array}$ \\
All deaths 1722-6 & 33 & 7 & 10 & 8 & 3 & 9 & 9 & 12 & 6 & 95 \\
All deaths 1727-9 & 22 & 4 & 5 & 10 & 9 & 10 & 18 & 14 & 8 & 151 \\
Fever deaths 1727-9 & 6 & 6 & 6 & 9 & 12 & 14 & 27 & 2 & - & 70 \\
\hline Powick & & & & & & & & & & \\
All deaths 1715-26 & 32 & 13 & 15 & 14 & 14 & - & 12 & - & - & 103 \\
All deaths 1727-30 & 22 & 3 & 12 & 15 & 12 & 14 & - & 22 & - & 137 \\
All deaths 1731-40 & 27 & 7 & 11 & 16 & 17 & 16 & 4 & 2 & - & 96 \\
\hline
\end{tabular}

one and one that can be tested wherever family reconstitution studies are made. ${ }^{33}$

If it is tentatively accepted for the purposes of argument that the higher age groups accounted for a disproportionately high percentage of the deaths between 1727 and 1730 then the demographic consequences of the fevers need some reassessmemt. If the deaths were concentrated amongst the aged then their impact on marriage would be lessened. Roughly half of the aged deaths would have been of women and therefore largely irrelevant to the issue of marriage age. It is in commonsense terms possible to envisage marriages delayed because of the existence of an aged female parent, but even if such considerations were not foreign to eighteenth-century patterns of thought, ${ }^{34}$ the number would not be statistically significant. Nor would the heavy death rate of aged men have major repercussions on marriage age. Such deaths could well mean an increase in wealth to the sons and daughters who inherited; it seems likely, however, that many of them would already have been married. Although some sons and daughters must have had their marriage prospects enhanced by the death of aged parents many of them would be too old themselves to found productive marriages.

Marriage allegations provide what seems to be a satisfactory indication of the influence of the epidemics on marriage age. Those who wished to marry without publication of banns had to obtain a licence from an archdeacon or his surrogate. In order to obtain this licence they had to provide a sworn statement, or allegation, declaring that canon law had been complied with and that there were no legal impediments to the projected marriage. Many thousands of allegations have been deposited in the Worcestershire Record Office and each gives the age and status of the potential groom and bride. ${ }^{35}$ Although by the end of the eighteenth century all attempt to record

33 If the older age groups did suffer with exceptional severity there could be confirmatory evidence of this in poor law expenditure. The Powick poor law records for the decade 1731-1740 are fragmentary but for the years that remain there is a reduction in costs from the level of the 1720 s and a reduction in the number of people on weekly pay.

s4 P. Laslett, The World We Have Lost, 1965, p. 91.

85 W.R.0.797 B.A.2036. 


\section{Impact of the Epidemics of 1727-1730 in South West Worcestershire}

an accurate age had been abandoned for the routine formula, 'aged twenty one years and upwards', the ages are given in the first half of the century and apparently with some accuracy. It is an easy matter to check the accuracy of the ages given in the allegations of Powick inhabitants by reference to the family reconstitution forms. These show little evidence of falsification or error and none amongst those aged less than thirty years. In a more general way a distribution analysis can be made of the ages given in large numbers of allegations. If this shows concentrations at certain ages, particularly quinquennial or decennial ages, it would imply that the ages given in the allegations were approximations. Such an analysis was made of 500 marriage allegations filed in 1739 and 1740.84 per cent of the bachelors and 86 per cent of the spinsters declared ages between twenty-one and thirty years. The distribution of these ages is given in Table 4.

Table 4

Distribution of Marriage Allegation Ages (The figures given are percentages)

\begin{tabular}{|l|c|c|c|c|c|c|c|c|c|c|c|c|}
\hline & Minor & 21 & 22 & 23 & 24 & 25 & 26 & 27 & 28 & 29 & 30 & $30+$ \\
\hline Bachelor & 2 & 6 & 13 & 13 & 10 & 9 & 8 & 8 & 4 & 3 & 10 & 14 \\
\hline Spinster & 8 & 10 & 15 & 13 & 10 & 8 & 9 & 4 & 4 & 1 & 12 & 6 \\
\hline
\end{tabular}

The pattern of distribution is disrupted unnaturally at thirty years. This indicates that something like one in ten of the bachelors and one in eight of the spinsters gave an approximation rather than a precise age. This habit is likely to have involved people of both sexes who were younger as well as older than thirty, probably it involved people whose ages ranged from twenty-eight to thirty-two years. Such a rough balance between under- and over-statement of age is unlikely to invalidate any calculation of the mean ages at marriage. ${ }^{36}$ This is true also for the ages over thirty where about half the ages cluster at quinquennial or decennial figures; moreover these represent a small proportion of the total numbers. The distribution of the ages given in the allegations is not such as to discredit them as a source of information on age of marriage in the first half of the eighteenth century; under thirty years when most of the marriages were contracted ages appear to have been accurately stated.

Allegations were declarations of the intention to marry rather than proof of marriage but for the great majority marriage followed. Marriage by licence was more expensive than the ordinary form of marriage but it is obvious from the social status recorded on the allegations that all classes of society, bar the labourer, married in this way. The number of husbandmen who married in this way shows the custom was not confined to the wealthy. Marriage by licence was the exception rather than the rule, used from motives of haste, convenience or social ostentation. None of these facts invalidates the use of the allegations as a source of evidence for marriage patterns in the first half of the eighteenth century.

Five hundred of the Worcestershire allegations were studied for each of four periods; 1709-10, 1719-20, 1729-30 and 1739-40. The variations in marriage pattern

${ }^{36}$ See below, p. 290. Cf. J. Lee, 'Marriage and population in pre-famine Ireland', Econ. Hist. Rev., 2nd ser., 1968, 21, 289-91. 


\section{J. A. Johnston}

revealed by this study are summarized in Table 5 . There would appear to have been no immediate reduction in the age of spinster marriage as a consequence of the epidemics, indeed there is a slight increase. The age of bachelors at marriage does show a decrease in 1729-30 and the decline is continued on into the period 1739-40, but neither for brides nor grooms is there the marked change in marriage age that might have been expected. One reason for this must have been the change revealed in sections (b) and (c) of Table 5. Usually about one in eight of the brides who married in the early eighteenth century was a widow, and one in five of the grooms a widower, in 1729-30 the proportions changed to one in four for both. At the same time the percentage of minors who married declined sharply. The percentage of marriages between bachelors and spinsters aged less than thirty years remained the same in all four periods at 52 per cent. The main marital reaction to the epidemics was the reconstruction of family units in which a widow or a widower formed one or both of the partners. Where one of them was linked to a partner who had not previously been married he or she drew upon a group of surplus unmarrieds large enough to make marriage to minors even more uncommon than it had been. Another indication of this reconstruction of family units in which age seems to have been preferred to youth is the fact that one in four of the couples married 1729-30 were separated in age by more than eight years. In the other three periods only about one in seven of the couples was separated by such a gap. The epidemics led to more marriages between 1727 and $1736^{37}$ but the evidence of the allegations does not point to any startling change in marriage habits and gives little support to the theory that the increased baptisms of the 1730 s are a result of younger marriages. ${ }^{38}$

The evidence from the Powick family reconstitution agrees to some extent with that of the marriage allegations. The status of both partners can be ascertained for twenty-six marriages between 1727 and 1734; 16 of them were between bachelor and spinster, 7 between widowers and a spinster, 2 between widower and widow and 1 between bachelor and widow. The mean age of spinsters at marriage (17) $)^{39}$ from 1727 to 1740 was 26.3 , for bachelors (17) it was 27.7 years. This is a substantial decrease from the mean ages at marriage of spinsters and bachelors who were born between 1663 and 1700, 30.5 years (38) and 31.8 years (21) respectively, but in Powick this reduction in marriage age is noticeable from the beginning of the eighteenth century. The mean age of marriage of the first 6 spinsters and bachelors who married after the onset of the epidemics was very low indeed, 22.4 years for brides and 24.2 for grooms. 8 of the widowers from the epidemics married on average 2.01 years after the death of the wife, the shortest interval before remarriage being 4 months, with 2 others remarrying before a year.

The evidence from Powick makes it possible to say something about one of the most remarkable features of the epidemics, namely the sharp decline in the number of baptisms that began in 1728 and continued for three years. One Powick couple, Walter and Anne Aldridge, were married in February 1723. They had three children, in February 1724, June 1725 and March 1727. Their next child was born in December

${ }^{37}$ See Table 1 above.

${ }^{88}$ Cf. D. E. C. Eversley, 'Population in Worcestershire 1660-1850', in Population in History, 1965, p. 409.

${ }^{39}$ The number of examples from Powick on which the mean is based is given in brackets. 


\section{Impact of the Epidemics of 1727-1730 in South West Worcestershire}

Table 5

Marriage Allegations and Marriage in Worcestershire 1709-40

a) Mean age at marriage

\begin{tabular}{|c|c|c|c|c|}
\hline & Spinster & Widow & Bachelor & Widower \\
\hline $1709-10$ & 25.68 & 37.22 & 26.98 & 39.02 \\
\hline $1719-20$ & 25.31 & 38.81 & 27.18 & 41.90 \\
\hline $1729-30$ & 25.76 & 36.04 & 26.68 & 39.13 \\
\hline $1739-40$ & 25.41 & 38.01 & 26.00 & 40.21 \\
\hline
\end{tabular}

b) Percentage of minors at marriage

\begin{tabular}{|c|c|c|c|}
\hline & Groom & Bride & Both Partners \\
\hline $1709-10$ & 3 & 11 & 1.0 \\
\hline $1719-20$ & 3 & 9 & 1.0 \\
\hline $1729-30$ & 1 & 5 & 0.2 \\
\hline $1739-40$ & 2 & 8 & 0.6 \\
\hline
\end{tabular}

c) Marital status before marriage (percentages)

\begin{tabular}{|c|c|c|c|c|}
\hline & Bachelor & Spinster & Widower & Widow \\
\hline $1709-10$ & 84 & 90 & 16 & 10 \\
\hline $1719-20$ & 81 & 85 & 19 & 15 \\
\hline $1729-30$ & 74 & 76 & 26 & 24 \\
\hline $1739-40$ & 83 & 86 & 17 & 14 \\
\hline
\end{tabular}

d) Percentages of marriages between people of different marital status

\begin{tabular}{|c|c|c|c|c|}
\hline & $\begin{array}{c}\text { Widow to } \\
\text { Widower }\end{array}$ & $\begin{array}{c}\text { Widower to } \\
\text { Spinster }\end{array}$ & $\begin{array}{c}\text { Bachelor to } \\
\text { Widow }\end{array}$ & $\begin{array}{c}\text { Bachelor to } \\
\text { Spinster }\end{array}$ \\
\hline $1709-10$ & 3 & 13 & 6 & 78 \\
\hline $1719-20$ & 6 & 12 & 9 & 73 \\
\hline $1729-30$ & 9 & 16 & 13 & 62 \\
\hline $1739-40$ & 5 & 12 & 9 & 74 \\
\hline
\end{tabular}

1732 and they subsequently produced another five children in $1735,1737,1738,1740$ and 1742. Another thirteen Powick couples can be identified from the family reconstitution forms who produced children before 1727 and after 1729 but none of whom had children in the two years of 1728 and 1729. Between them these families produced thirty children in the period 1724-7 and 43 between 1730 and 1742, but none in 1728 and 1729. These fourteen families must represent about a twelfth of the families in the parish and a considerably greater proportion of the families capable of producing 


\section{J. A. Johnston}

children. Even though the registers would not record induced miscarriages, abortions or much infant mortality the break in the common reproductive pattern of all these families whereby they produced a child roughly every two years is remarkable. There seems to have been no higher incidence of deaths during pregnancy or at birth amongst mothers or children in Powick or in neighbouring parishes which might help to explain the reduction in baptisms. The harvests of 1726 and 1727 are not so bad as to explain the first year of the reduction though by 1729 after two bad harvests scarcity of food could be a major factor. The motives and methods involved in this apparently deliberate limitation of births remain obscure.

The study of Powick adds little more to the story of the epidemics. Both rich and poor suffered as did the settled families and those more mobile. Some of the wealthiest yeoman families were hard hit, two of the leading forty-shilling freeholder families losing five members each. But the wealthiest did not suffer excessively. Twenty-three of those who died in Powick during the epidemics left probate inventories listing assets valued at $£ 2,189.4^{40}$ The mean value of these inventories, $£ 95$, is not strikingly different from the $£ 90$ mean of the twenty-three Powick inventories left between 1721 and 1726. Initially it seemed that the high number of deceased in the epidemics who came from families not established in the parish made it possible that the mortality was particularly severe on the mobile elements of the labouring class. However, Powick enjoyed a high level of mobility and it is likely that some at least of the stranger burials of the period were of 'refugees' from the more dangerous environment of Worcester.

There are no surviving direct literary references to the epidemics in south west Worcestershire in diaries, letters or parish documents. To the contemporaries no one of the bad years on its own could have seemed extraordinary. Each would have been experienced as simply just another of the periodic epidemics to which they were inured. The impact of the fevers would have been diluted by time and by their diverse incidence in many rural communities, most of them largely self-contained. There must have been few people with a knowledge of many parishes, the ability to discern a unity in the years from 1727 to 1730 as well as the interest and literacy to record their account of events. Thus a mortality which, if it had been concentrated in a single year, would have ranked with the great disasters of English history provoked little mention in Worcestershire or in the country as a whole. The most obvious marital reactions to the deaths was not apparently a reduction in the age of marriage but remarriages by widowers and widows and, amongst the survivors who were already married and the newly married, a readiness to rear more children. The economic conditions of the 1730s favoured the survival of these children, harvests were generally good, the fathers of these families must have found jobs easy to obtain. This can only be a partial explanation of the increasing birth rate of the 1730s. There is no way of certainly evaluating the psychology of a past society that has just emerged from four lean years. It could well have been a younger society than any the eighteenth century had so far seen if the fevers had indeed been particularly fatal to the older age groups but the motivation of the numerous baptisms of the 1730s remains as uncertain as that for their reduction in 1728 and 1729.

${ }^{\text {} 0}$ W.R.O. 008.7 B.A.3585/424-464. 